\title{
The Bureaucratic Perception of Policy Options*
}

\section{P. Moore}

There was once a time when white 'expert' social scientists could go to a developing country, analyse a problem, produce a set of recommendations, and return to base with a clear conscience feeling that their job was done. If 'politics' resulted in the non-acceptance or non-implementation of their recommendations, then so be it. Such practices are still not uncommon. But if today the expert is rash enough to talk about his mission at the IDS or some similar institution, he is likely to be forced to justify his work politically. That is to say, he is expected to produce an analysis of the political structure of the country in question, and to explain which political interests will benefit from, and therefore support, his recommendations. His work as an adviser is judged not only by his technical competence, but in the light of his ability to tailor and present recommendations in such a way that they will gain the support of powerful political interests, or at least help arouse the un-politicised poor. The adviser who simply argues that policies $\mathbf{A}$ and $\mathbf{B}$ will be good for country $\mathrm{C}$ is considered to have done only half a job, and likely to be characterised (or caricatured) as naïve.

Such a trend is on the whole refreshing; it has the merit of making explicit the political nature of advisory work, and makes for more interesting seminars. The technical specialist, especially the economist, is forced to look beyond the disciplinary boundaries of his technical specialism. The question to which this paper addresses itself is whether the wholesale invasion of the field of political analysis by non-political-scientistsespecially economists-always produces sensible or useful political analyses.

It seems to this author that the combined forces of the politically-awakening economists and the politically-awakened neo-Marxists tend to confine discussions within the limits of a model of the political process which is rather too narrow to be accepted even as a necessary over-simplification of the world. One might call this the 'powerinterest' model: policy is to be understood primarily as the expression of the interests of socio-economic groups and categories which exert leverage at some stage in the political process. Thus-and may my colleagues pardon me-so

\footnotetext{
* The author is grateful to his colleague Bernard Schaffer for
} comments on an earlier draft. many of our discussions fall into a repetitive pattern: the first speaker explains why country $X$ should adopt such and such a policy; the second speaker explains why that is impossible because it conflicts with the interests of groups A and B. Later speakers go on to discuss the feasibility of alternative policies or alternative political alliances, but always within the confines of the model which directly links group interests to policy.

Professional political scientists of course find the 'power-interest model'-and the present author's discussion of it-absurdly elementary. They are able to tell us a great deal more about how political institutions actually work. This author does not intend to re-work old ground, but rather to examine the general issue from a rather different vantage point, and to focus on how 'bureaucrats' - the actual agents and often the instigators of government policy-appear to perceive policy options. The conclusion to which this paper points is that, at least in certain spheres, the connection between interest and policy is far from direct, but is mediated by the particular perceptions of those in administration about the range of measures which are feasible in respect of rural development. In other words, a great deal never gets done not (just) because it conflicts with powerful interests, but because it is simply never considered.

\section{Rural development and 'programmatism'}

A vantage point for examining the question of bureaucrats' perceptions of policy options was provided by attending within a relatively short space of time two conferences on rural development held in two developing countries situated in different continents. The precise character of these conferences is important to the argument which follows. Both were concerned with rural development in the respective countries, and organised by local university staff. In both cases the overt concern was practical-i.e. with the formulation of policy recommendations; a certain amount of political backing had been given. Most important, the majority of participants were not academics, but regular staff of local Ministries of Agriculture and related government agencies-departments of co-operatives, irrigation, and rural development, rural banks, regional development authorities, etc. The numerical pre- 
dominance of these bureaucrats ${ }^{1}$ exerted a major influence on the tone and content of papers and discussions. Debate was relatively uninhibited and points of conflict between departments often given an airing. Few expatriates were present in either case. One assumes that, since many of the bureaucrats were sacrificing weekends and working time to attend the conferences, they tended to be those whose concern about rural development was the most genuine. In sum, the situations were such that one could obtain a fairly good insight into how the bureaucrats perceived the issues in rural development.

This author was struck not so much by the specific content of the discussions as by the remarkable identity of outlook which was exhibited by the two sets of bureaucrats. This outlook was characterised by a rather narrow and rigid view of what represented the permissible/possible range of government activities to promote rural development. In particular, one was left with an overwhelming impression of 'programmatism', i.e. a view that the only way to tackle 'problems' is to run 'programmes'-departments must be allotted responsibility, staff appointed, the problem defined and categorised, and sets of prescribed services provided. These services may include: supplying fertilisers; building 'growth poles' with ready-made dispensaries, garages, lorry-parks, local government offices, schools and football pitches; transporting and supplying spare parts for tractors or outboard motors; regulating tractor hire charges; supplying certified seed; establishing and supervising co-operative credit facilities; building irrigation dams and improving marketing systems. Provided that the public, politicians and other government departments pull their weight, there is nothing that cannot be provided!

\section{The excluded alternatives}

That government departments should display eagerness to provide more services to the public is in itself very laudable. The trouble lies in the alternatives which a 'programmatist' world-view appears to preclude. Specifically, it appears to preclude serious consideration of two broad alternative kinds of government intervention in the rural sector: on the one (right?) hand, the use of price policy to channel resources into desired activities-and this in countries where government control over prices ranges from 'substantial' to 'near complete'; on the other (left?) hand, what might broadly be called 'mobilization strategies', i.e. government stimulation of a broad range of self-help and communal labour schemes.

1 The word 'bureaucrat' is used entirely non-pejoratively.
The latter might cover adult education; dissemination and discussion of technical advice in agricultural production; health and hygiene, construction of local infrastructure in the form of roads, bridges, drainage ditches, snall-scale dams and dispensaries; and co-operative processing and marketing of output; or local initiative in the formulation of development projects.

In the context of these two conferences, the evidence for the prevalence of 'programmatist' ideologies is not of a kind which would satisfy a court of justice. It lies less in what was said than in what was left unsaid or ignored. For example, occasional attempts (by economists) to introduce the concepts of prices, incentives and efficient resource use were largely stifled in a mixture of disinterest and apparent non-comprehension. Attempts to discuss 'mobilization strategies' were by implicit consensus referred to officials of cooperative departments, and diverted into discussions of the reasons for the malfunctioning of cooperatives. Real interest was sparked largely by issues which could be played out on the 'admininstrative chess board'. Should there be a threeor four-tier structure of local government? Should extension be crop-specific or integrated? What should be the qualifications for directors of regional development authorities? Should the rural offices of all government agencies be grouped together in one place? In general, 'programmatism' warms to discussions in which the public can be ignored or simply seen as so many pawns. It shies away when the public starts doing something untutored, regardless of whether that something be increasing the output of coconuts because of an increase in the market price, or cooperating with neighbours in establishing an informal mutual credit scheme.

Before saying anything in detail about the possible reasons for the prevalence of "programmatist' ideologies, let us examine its consequences. One might be tempted to dismiss the whole issue as something rather peripheral were its main consequences limited to marginal choices about roughly equivalent sets of policies. But that, unfortunately, does not seem to be the case. Let us look at the issue of rural-urban relationships and, specifically, the theory of 'urban bias'z. It is clear that one of the ways in which many developing countries-including the two considered here-transfer income from rural to urban sectors is by maintaining an over-valued exchange rate. This in general favours the sector which uses most imports--i.e. the urban-industrial sector-and specifically encourages the im-

2 A book on the subject of 'urban bias', by my colleague, Michael Lipton, is due to be published' in 1976. 
port of food, thus depressing food prices and the incomes of the rural population. At the same time, an over-valued exchange rate 'relieves' local producers of agricultural export commodities of a proportion of the world market value of their produce. Both countries in question have been able to maintain grossly over-valued exchange rates because a large proportion of their rural populations and resources are 'locked into' a situation of dependence on receipts from treecrop exports. In the medium-term, the rural producers can do little except accept the prices offered and invest their energies and financial surpluses in other activities.

While the prevalence of 'urban bias' in these and other developing countries may be due largely to the play of political interests, another important aspect of the problem is that the government departments which ought normally to protect rural interests are staffed by people whose perceptions of policy-making make them ill-fitted to defend rural interests over the really big decisions. Because bureaucrats do not appear to conceive of the ordinary farmer as an economic animal, and because they can conceive of helping the rural population only via their own programmes, they do not discuss rural development in terms of prices, incentives and resource allocation; they are in many cases apparently not even aware that decisions about, for example, the exchange rate, may have more effect on rural output and welfare than all the efforts of the extension, irrigation and cooperative services put together.

\section{The 'logic of bureaucracy'?}

There are few people who are willing to forgo the pleasures of complaining about both 'bureaucracy' in the pejorative sense-i.e. 'red tape', unnecessary obstruction and complication-and 'bureaucracy' in the sociological sense-i.e. routinised administration, characterised by formal procedure, de-personalization, hierarchy, precise specification of job functions and very limited and prescribed scope for discretion about the application of rules. Most of us are quick to detect and complain of bureaucracy (in either sense) in organisations other than our own. 'Programmatism' is clearly in some sense a characteristic of bureaucracies, and an excess of bureaucracy has often been diagnosed as a major cause or symptom of the under-development of excolonial societies. Is there then anything novel in the present author's argument? The answer to that question depends on the closeness of the necessary connection between bureaucratic modes of administration and the phenomenon of 'programmatism'. That there is a certain degree of necessary connection cannot be doubted: bureaucracies by nature tend to favour routinised rather than innovative activities, are best fitted for control, and tend to disaggregate and simplify total situations in ways which make easier the application of standard rules, but militate against a comprehension of the situation. ${ }^{3}$ These characteristics clearly favour the development of an ideology similar to that of programmatism. In particular, they make it especially difficult to pursue 'mobilization strategies' of the kind outlined above. However, it is far from clear that the imperatives of bureaucratic organisations can fully account for programmatist ideologies. The imperatives of bureaucratic organisation may determine how a bureaucracy will set about achieving a stated goal; they do not seem to explain why the particular bureaucracies in question should be so possessive in their desire to accomplish all goals through their own programmes, and so uninterested in the possibility of alternative means to the same ends. Many bureaucracies function happily in societies in which a substantial proportion of decisions about resource allocation are taken through the market mechanism. There is no 'iron law' of the expansion of the sphere of operations of government bureaucracies.

\section{Class interest?}

The prevalence of 'programmatism' would then seem to require some independent explanation. One possible explanation which will occur to many, and which certainly contains part of the truth, would perhaps lie in the argument that the interests of bureaucrats-whatever the ministry they belong to-are the interests of the urban middle class. That is, the actions, and ideologies of bureaucrats are largely an expression of a class interest. Low food prices suit the Ministry of Agriculture, if not agriculture. The Cooperative Department shows no interest in 'mobilization' because that would endanger its political control of the rural population. Such arguments have an appeal, but there are too many unexplained exceptions. If the Cooperative Department is primarily interested in political control, why is it happy to ignore the existence, in one small region in which one of our conferences was held, of several dozen totally informal but successful small-scale sugar production cooperatives? At another level, why, in a world in which it is feared that political power will accrue to the holders of food surpluses, do food-deficit governments not achieve independence of this threat by taking more vigorous steps to achieve food self-

\footnotetext{
3 C.f. Bernard Schaffer, "The Deadlock in Development Administration" in C. Leys (ed.), Politics and Change in Developing Countries, Cambridge University Press, 1976.
} 
sufficiency? Even when analyses of rural development policies purely in terms of political interests manage to free themselves of tautology, they still seem to leave some questions open.

\section{Life styles and intellectual frameworks}

A further partial understanding of "programmatism' may be found in looking at the socioeconomic characteristics of the two countries concerned: relative to other countries in their respective regions, each has a lengthy history of relative affluence based on the export of one primary agricultural commodity; each has a rich and Anglicised élite, and attained early independence from the colonial power with relatively little effort. It may be that the life styles and ideologies of these élites have exerted a baneful influence on administrative capacity, particularly where this demands some empathy or contact with the rural population. In this connection, it seems important that we are talking of officials concerned with rural development: 'programmatism' may be less in evidence in areas of government activity where the social and cultural gap between officials and clients is less wide.

Finally, and by way of a conclusion, a word about the way in which 'programmatism' appears to find justification in the transfer of 'intellectual technology'. In one of his early exercises in castigating the United Nations, and especially its alleged domination by the Third World, the former US Ambassador (to the UN) Daniel Moynihan, asserted that the developing countries -and thus the UN--were ridden with ideologies, stemming directly from British Fabianism, which justified and encouraged a rather drab form of interventionist state capitalism. Pardoning the exaggeration, this claim appears to contain a certain truth. Many people in responsible positions in the developing world, along with this author and many current students, were taught by left-wing lecturers that the British/American development experiences are poor models for developing countries, and that objective conditions within the latter and within the world economy are such as to necessitate large-scale state economic intervention. For a variety of reasons-probably few of which are related to the content of student lectures-extensive government economic intervention is the rule in almost all developing countries, whatever their political complexion. It is unfortunate that attempts to debate the nature and content of that intervenion are sometimes interpreted simply as arguments for laisser-faire and 'rebutted' with the words of lecturers who, in many cases, have since learned that the pillars of North European social democracy often change shape under the stress of tropical climate. 